\title{
Operational Feasibility Assessment of Geothermal Heat Harnessing Systems
}

\author{
FERENC SZODRAI ${ }^{1}$, FóRIÁN ZSOLT LAJOS ${ }^{2}$ \\ ${ }^{1}$ Department of Building Services and Building Engineering, University of Debrecen, Faculty of \\ Engineering, Ótemető u. 2-4, H-4028 Debrecen, Hungary, szodrai@eng.unideb.hu \\ ${ }^{2}$ Department of Building Services and Building Engineering, University of Debrecen, Faculty of \\ Engineering, Ótemető u. 2-4, H-4028 Debrecen, Hungary (student)
}

\begin{abstract}
Renewable energy sources are now essential to establish sustainable development. This paper examines one kind of source the geothermal energy. For geothermal energy when combined with a heat pump COP can be used for evaluation. For solely geothermal sources different approach is needed thus in the paper, a new geothermal heat production coefficient is used to examine the operational feasibility. For the assessment, many hypothetical buildings were created to model their heat demands. Two types of calculation methods are used for heat demand calculation. Based on the results, the maximum depth of a geothermal borehole and economically critical qualitative coefficient was concluded.
\end{abstract}

keywords: geothermal, NZEB, building energetics, renewable energy

\section{Introduction}

Low enthalpy geothermal heat harnessing systems (GHHS) can be excellent carbon-free heat sources for larger buildings or even district heating systems [1], [2]. These systems usually require a borehole in which an adequate temperature and a pump that extracts the liquid [3]. The rest of the heating system which directs the heat to the users can be the same as at any alternative heat source (e.g., gas boiler, heat pump). The paper focuses on the low enthalpy geothermal regime since in Hungary the wellhead temperature $\left(\mathrm{T}_{\mathrm{WH}}\right)$ is low (below $90^{\circ} \mathrm{C}$ ) thus no steam (except a few cases e.g. Tura powerplant) can be utilized to produce electricity in turbines [4]-[6]. Low enthalpy GHHS is usually used to produce warm water which can serve as a cover of heating, domestic hot water (DHW) and/or balneology demands [6].

GHHS borehole depth can be shallow and deep. If the geothermal liquid is extracted from a few metres depth which leads to low investment cost, however shallow depth usually has low $\mathrm{T}_{\mathrm{WH}}$ thus additional heat sources are needed to ensure the steady operation. When geothermal liquid is extracted a few km deep the initial investment cost can be high, though it can deliver the total heat amount solely. [7], [8]

When heat pump used as a heat source of a system the coefficient of performance (COP) and seasonal coefficient of performance gives a value that helps the engineer to decide whether the system viable or not. For geothermal systems viability depends more on the location and 
utilization rather than the actual efficiency of the devices, thus a new geothermal heat production coefficient (GHPC) is introduced. To evaluate the applicability of the newly introduced coefficient numerous hypothetical GHHS were created and analysed.

In section 1.1 GHPC calculation method is presented, sections 1.2 and 1.3 building models are created for the GHPC evaluation. In section 2 results are discussed.

\section{Materials and Methods}

\subsection{Geothermal Heat Production Coefficient}

The evaluation of GHHS is approached by a well-known quantity the coefficient of performance with a different point of view, for heat pumps COP is described with equation 1.

$$
C O P=\dot{Q}_{h p} \cdot \dot{P}_{c}^{-1}
$$

where $Q_{h p}$ is heating power produced by the heat pump and $\dot{P}_{c}$ is the electric power demand for this performance. The presented methodology differs, and it does not focus on the device but instead on the system. A GHHS that extracts a warm liquid from the ground can be operated with a deep well pump (DWP). This GHPC can be expressed as the following:

$$
G H P C=\dot{Q}_{h e} \cdot \dot{P}_{D W P}^{-1}
$$

which is the ratio of the extracted heat $\left(\mathrm{Q}_{\mathrm{he}}\right)$ and the pumping power demand $\dot{\mathrm{P}}_{\mathrm{DWP}}$. The extracted heat is calculated with equation 3 and pumping power demand with equation 4, respectively.

$$
\dot{Q}_{\text {Heat extracted }}=c \cdot \dot{m}_{u} \cdot\left(T_{W H}-T_{c}\right)
$$

where $\mathrm{c}$ is the specific heat of the extracted liquid $\left[\mathrm{J} \cdot \mathrm{kg}^{-1} \cdot \mathrm{K}^{-1}\right], \dot{\mathrm{m}}_{\mathrm{u}}$ is the mass flow rate of the liquid which was utilized by the system in $\left[\mathrm{kg} \cdot \mathrm{s}^{-1}\right], \mathrm{T}_{\mathrm{WH}}\left[{ }^{\circ} \mathrm{C}\right]$ is the production well wellhead temperature and $\mathrm{T}_{\mathrm{c}}\left[{ }^{\circ} \mathrm{C}\right]$ is the temperature that the liquid was cooled down by the geothermal heat harnessing system.

$$
\dot{P}_{D W P}=g \cdot \dot{m}_{D W P} \cdot\left(z_{r e f}-z_{e x}\right)
$$

In equation 4 , g represents the gravitational acceleration which is $9.81 \mathrm{~m} \cdot \mathrm{s}^{-2}, \dot{\mathrm{m}}_{\mathrm{DWP}}$ is the mass flow rate of the deep well pump, $z_{\text {ref }}$ is the depth of reference level where the pump delivers the liquid to the system and the $\mathrm{z}_{\mathrm{ex}}$ is the depth level of the pump. Combining equations 2,3 and 4 followings can be expressed:

$$
G H P C=c \cdot \dot{m}_{u} \cdot\left(T_{w h}-T_{c}\right) \cdot\left(g \cdot \dot{m}_{D W P} \cdot\left(z_{r e f}-z_{e x}\right)\right)^{-1}
$$

Based on equation 5 the GHCP depends on the specific heat of the liquid, the utilisation rate of the geothermal liquid which can be used as " $u$ " and by the properties of the geothermal source extraction named as production gradient $\nabla p$.

$$
G H P C=c \cdot u \cdot \nabla p \cdot g^{-1}
$$

\section{Decree based heat demand}


For the evaluation of the GHCP, several hypothetical GHHS heat demands were created. The idea was that with different magnitude of heat demands the GHCP deviation can be examined, thus a clearer view of this coefficient can be established. For the heat demand, the heat losses of the building and the DHW demand is counted in. It is possible to cover the cooling demand of building with geothermal heat sources [9], [10], however, this paper focuses on heating degree-day based heat demand calculations [11]. Buildings that are heated with geothermal liquids are often combined with spa, which can increase the heat demand, in this paper this kind of energy demand is not calculated since the magnitude of heat could vary independently. For the calculations buildings had heat demands which magnitude changed by the type and the size of the building. The size changed in the function of heated area and volume also known as the A/V ratio. The building with scaling A/V ratio was firstly used in Szodrai et al. [12]. It started with a $10 \mathrm{~m}-$ by- $10 \mathrm{~m}$ base area, then its length increased up to $200 \mathrm{~m}$. At every $20 \mathrm{~m}$ length increase the initial $2.7 \mathrm{~m}$ base height was added. For simplification, the $2.4 \mathrm{~m}^{2}$ large door was constant and the glazed area of the building was $12.5 \%$ of the net building area. Every property of the building was exactly the magnitude of the nearly zero energy building requirement defined by the Decree on the Determination of the Energy Characteristics of Buildings (Decree) [13]. This Decree [13] describes the calculation method of the heat energy demand $\mathrm{Q}_{\mathrm{H}}$ calculation which consist of two parts, the heating and the DHW energy demand and it is expressed as the following in equation 7 :

$$
Q_{H}=H \cdot V \cdot(q+0,35 \cdot n) \cdot \sigma-Z \cdot A_{n} \cdot q_{i}+A_{n} \cdot q_{D H W}
$$

where $\mathrm{H}(72 \mathrm{hK})$ is the thousandth of standardized heat bridge value of the heating season in Hungary; $\mathrm{V}$ is the heated volume of the building $\left[\mathrm{m}^{3}\right]$; $\mathrm{q}$ is the specific heat loss coefficient $\left[\mathrm{W} \cdot \mathrm{m}^{-}\right.$ $\left.{ }^{3}\right]$; $\mathrm{n}$ is the air change ratio of the building $\left[\mathrm{h}^{-1}\right]$; $\sigma$ is the intermittent heating coefficient; thousandth length of the heating season [kh]; $A_{n}$ net base area $\left[\mathrm{m}^{2}\right]$; $\mathrm{q}_{\mathrm{i}}$ magnitude of the internal specific heat source $\left[\mathrm{kWh} \cdot \mathrm{m}^{-2} \cdot \mathrm{a}^{-1}\right]$ and $\mathrm{q}_{\mathrm{DHW}}$ represents the specific DHW consumption $\left[\mathrm{kWh} \cdot \mathrm{m}^{-2} \cdot \mathrm{a}^{-1}\right]$. The values for equation 7 are presented in table 1 for residential, office and educational types of buildings.

\begin{tabular}{ccccc}
\hline type & $\mathrm{n}\left[\mathrm{h}^{-1}\right]$ & $\mathrm{q}_{\mathrm{DHW}}\left[\mathrm{kWh} \cdot \mathrm{m}^{-2} \cdot \mathrm{a}^{-1}\right]$ & $\sigma$ & $\mathrm{q}_{\mathrm{i}}\left[\mathrm{kWh} \cdot \mathrm{m}^{-2} \cdot \mathrm{a}^{-1}\right]$ \\
\hline residential & 0.5 & 30 & 0.9 & 5 \\
\hline office & 0.8 & 9 & 0.8 & 7 \\
\hline educational & 0.9 & 7 & 0.8 & 9
\end{tabular}

Table 1. Heat demand calculation constants [13]

the specific heat loss which only depends on the building properties can be calculated as the following:

$$
q=\left(\sum\left(A_{j} \cdot U_{j}\right)+\sum(1 \cdot \psi)-\sum A_{\text {window }} \cdot g_{w} \cdot \varepsilon \cdot Q_{T O T} \cdot H^{-1}\right) \cdot V^{-1}
$$

where, $A_{j}$ - is the heated external surface of a part of the building $\left[\mathrm{m}^{2}\right] ; U_{j}$ - is the heat transfer coefficient of a part of the building $U_{\text {Wall }}=0.24 \mathrm{~W} \cdot \mathrm{m}^{-2} \cdot \mathrm{K}^{-1}$ heat transfer value of the wall; $U_{\text {Door }}=$ $1.45 \mathrm{~W} \cdot \mathrm{m}^{-2} \cdot \mathrm{K}^{-1}$ heat transfer value of the door; $U_{\text {Window }}=1 \mathrm{~W} \cdot \mathrm{m}^{-2} \cdot \mathrm{K}^{-1}$ heat transfer value of the window; $\mathrm{U}_{\text {Floor }}=0.3 \mathrm{~W} \cdot \mathrm{m}^{-2} \cdot \mathrm{K}^{-1}$ heat transfer value of the floor; $\mathrm{U}_{\text {Roof }}=0.17 \mathrm{~W} \cdot \mathrm{m}^{-2} \cdot \mathrm{K}^{-1}$ heat transfer value of the roof; $\mathrm{l}$ - is the length of the heat loss (the perimeter of the building) [m]; $\Psi$ - linear 


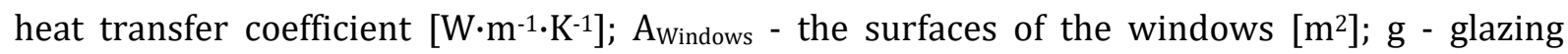
correction factor, for triple glazed windows $0.50 ; \varepsilon$ - buildings structure coefficient, for a heavily built building, is 0.75 and for light built is 0.5 ; $\mathrm{Q}_{\text {тот }}$ - specific internal solar energy gain, for north orientation is $100\left[\mathrm{kWh} \cdot \mathrm{m}^{-2}\right.$. [13]

\section{Location-based heat demand}

The heat demands were also calculated for a location to see how much difference between a dynamic is changing external temperature and solar radiation model and a steady simplified model. The chosen location was Létavértes since there is an actual geothermal system that can be found. From the data of the Climate Monitoring Satellite Application Facility (CM-SAF) [14] air temperature $\left(\mathrm{T}_{\mathrm{e}}\right)$ and the solar radiation (I) were gathered and used for the calculations.

The specific heat loss for a given hour is calculated by the following:

$$
\dot{\mathrm{q}}_{\mathrm{i}}=\left(\sum\left(\mathrm{A}_{\mathrm{j}} \cdot \mathrm{U}_{\mathrm{j}}\right)+\sum(\mathrm{l} \cdot \psi)-\sum \mathrm{A}_{\text {window }} \cdot \mathrm{g}_{\mathrm{w}} \cdot \varepsilon \cdot \mathrm{I}_{\mathrm{i}} \cdot \Delta \mathrm{T}_{\mathrm{i}}^{-1}\right) \cdot \mathrm{V}^{-1}
$$

Thus, the location-based annual heat demand becomes.

$$
Q_{H, D}=\sum\left(\Delta \mathrm{T}_{\mathrm{i}} \cdot \mathrm{V} \cdot\left(\dot{\mathrm{q}}_{\mathrm{i}}+0,35 \cdot \mathrm{n}\right)\right)-\mathrm{Z} \cdot \mathrm{A}_{\mathrm{n}} \cdot \mathrm{q}_{\mathrm{i}}+\mathrm{A}_{\mathrm{n}} \cdot \mathrm{q}_{\mathrm{DHW}}
$$

It is worth noting that in the calculation only the transmission losses and solar gains are changing hourly [15], the modelling of the fluctuation of the DHW demands and internal gain is a further goal.

\section{Results}

\section{Decree and location-based differences}

Twenty-three different sizes of buildings were created and examined with three different purposes (residential, office and educational) for cases when the heating degree days and radiation were given by Decree [13] and when it was location-based. The two sets of cases were compared, and the relative error was depicted in figure 1 to see the difference between the input sources. The office type of building had the lowest relative difference, while residential buildings had the highest difference. 


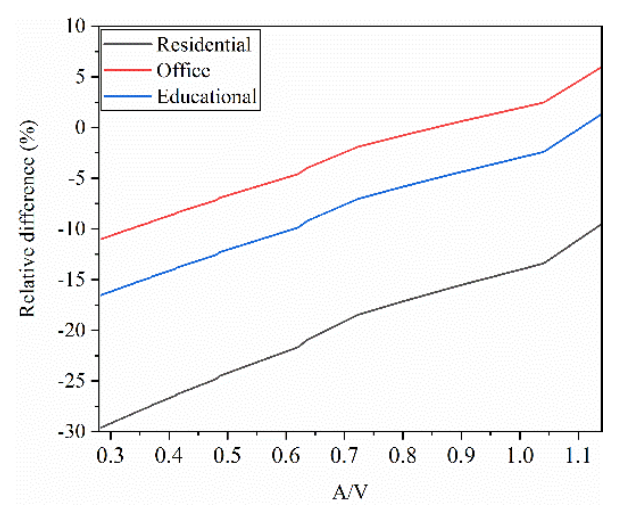

Figure 1. The relative difference between the location and Decree is based on external temperature and solar radiation data.

The three types of buildings curves had similar slopes on the figure 1 diagram, yet their magnitude was different, this can be attributed to the different specific internal heat gains and the DHW demand. The main reason for the difference is that when the demands are examined locally the input values are not standardized.

\section{Constant and variable extraction ratios}

For each type and size of building hourly heating, demand was calculated. When the heating demand was negative (cooling was needed), zero was given instead, to avoid the false reduction of the heating energy demand. According to this method, an accurate demand estimation can be predicted for variable flow extraction GHHS. If this method is applied, then the extracted heat amount is transferred to the utilization section of the building. The other extreme can be when the flow has to be constant, and it has to cover the highest heat demand. In this constant extraction scenario, the mass flow of the maximum heat demand is extracted from the geothermal source and kept at a constant level for the whole year. The ratios between these two extremes were calculated for every case and plotted in figure 2 as a box chart.

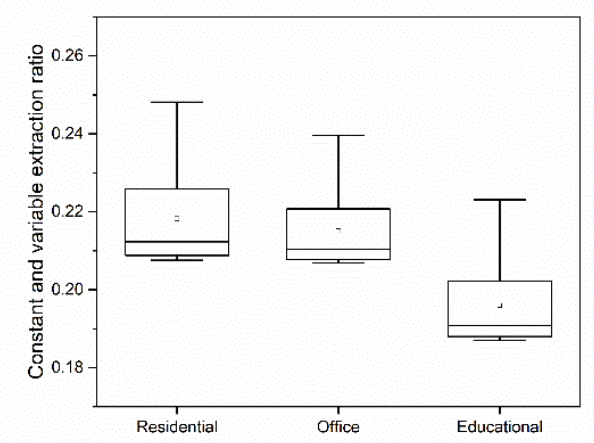

Figure 2. Constant and variable extraction ratios

The median of this ratio for residential and office buildings were 0.21 and for educational buildings, it has a slightly lower 0.19 magnitude. This means that by utilizing variable flow extraction the extracted heat energy can be reduced by approximately $80 \%$. Due to the response 
time (thermal lag, pumping, control valves) the variable flow represents an ideal scenario. For steady operation, a buffer can be applied before the heat centre.

\section{An economic evaluation of GHCP}

As in equation 2, it was expressed with the ratios of energies, an economic point of view gas and electricity price ratios can be used. Natural gas has the lowest specific $\operatorname{cost}\left(\mathrm{c}_{\mathrm{gas}}=0.0308 \mathrm{euro} \cdot \mathrm{kWh}^{-}\right.$ ${ }^{1}$ [16]) for heating in Hungary. Electric energy is used for pumping which price in Hungary is $c_{\text {eletricity }}=0.1009$ euro $\cdot \mathrm{kWh}^{-1}$ [17]. These prices are usually distorted due to the efficiency of the condensation boiler and the deep well pump and stock exchange. In this paper, the efficiency difference between the pump and boiler was assumed to be minimal (less than $\pm 5 \%$ ). With these assumptions, an economic GHPC was used to evaluate the viability of the GHHS.

$$
G H P C_{e}=e_{\text {eletricity }} \cdot e_{\text {gas }}^{-1}
$$

Solving equation 11 gives $\mathrm{GHPC}_{\mathrm{e}}=3.2$, which means that for a geothermal system to be economically feasible it has to extract three times of heat as it is consumed to pump the liquid where it is used.

For operational feasibility check the production gradient can be calculated by combining equations 6 and 11 were "constant and variable extraction ratios" as the utility factor $(\mathrm{u})$ and the specific heat for water $4200 \mathrm{~J} \cdot \mathrm{kg}^{-1} \cdot \mathrm{K}^{-1}$.

$$
\nabla p=G H P C_{e} \cdot g \cdot(u \cdot c)^{-1}
$$

For variable and constant flow extraction geothermal systems, it gives $\nabla p_{v}=7^{\circ} \mathrm{C} \cdot \mathrm{km}^{-1}$ and $\nabla \mathrm{p}_{\mathrm{c}}=36^{\circ} \mathrm{C} \cdot \mathrm{km}^{-1}$ respectively.

\section{Production gradient}

The geothermal production gradient depends on the system location and temperature requirements. The $\mathrm{T}_{\mathrm{WH}}$ defines what purposes can serve the GHHS. For example, DHW demands at least $60^{\circ} \mathrm{C}$ while for heating $\mathrm{T}_{\mathrm{WH}}$ could be reduced lower such as $35-40^{\circ} \mathrm{C}$. The minimum $\mathrm{T}_{\mathrm{WH}}$ defines the total depth of the geothermal borehole still, it is independent of the extraction/pumping ( $\mathrm{z}_{\mathrm{ex}}$ ) depth. If we assume that a building requires DHW, and the extracted liquid is cooled down to the lowest possible temperature around $20^{\circ} \mathrm{C}$ the critical pumping depth can be calculated. this critical depth tells what the maximum depth is where the GHHS is still feasible. For a variable flow GEHS, the critical depth is $5.7 \mathrm{~km}$ while at constant flow the value is $1.1 \mathrm{~km}$. With variable flow rate the DWP, more than five times deeper can be placed. For constant flowrate systems which are not feasible, variable flowrate could change its GHCP. In addition, where the cooled temperature is high whit additional heat utilizations it can be reduced [6].

It is worth noting that the maximum extraction depth is halved if the geothermal liquid is reinjected. It is because another pump is required to inject the liquid under the ground. This production gradient is a rough estimate since other losses from the system are disregarded. This gradient is strictly used for liquid state (low enthalpy) of geothermal fluids. 


\section{Conclusions}

A new Geothermal Heat Production Coefficient (GHCP) was introduced in this paper with a goal to examine the viability of the operation. This coefficient is the ratio of the extracted heat and the pumping power. This coefficient depends on the production gradient and the utilization rate. For the assessment heat (heating and domestic hot water) demand of sixty-nine nearly zero energy demand buildings were examined. Heat demand was calculated by following the Decree on the Determination of the Energy Characteristics of Buildings and using location-based input parameters. It was found out when the GHPC was calculated based on the electricity and natural gas price the production gradient can be solved. Which can predict the pumping depth or how much heat should the utilization system (building) harnesses from the geothermal liquid. Based on the result it can be concluded that if the pumping closely follows the heat demand the GHPC becomes more favourable. Systems with high GHCP could deliver geothermal water from deeper or it could operate at a low cost.

The proposed model contains plentiful constraints, in the future it is planned to examine the GHPC in case of reinjection, furthermore, to have a more realistic view for these kind of systems dynamic change of DHW and internal gains models should be added.

\section{Acknowledgement}

The publication is supported by the EFOP-3.6.1-16-2016-00022 project. The project is cofinanced by the European Union and the European Social Fund.

\section{References}

[1] M. Soltani et al., "A comprehensive study of geothermal heating and cooling systems," Sustain. Cities Soc., vol. 44, pp. 793-818, 2019, doi: 10.1016/j.scs.2018.09.036.

[2] P. Bayer, G. Attard, P. Blum, and K. Menberg, "The geothermal potential of cities," Renew. Sustain. Energy Rev., vol. 106, no. February, pp. 17-30, 2019, doi: 10.1016/j.rser.2019.02.019.

[3] P. Allahvirdizadeh, "A review on geothermal wells: Well integrity issues," J. Clean. Prod., vol. 275, p. 124009, 2020, doi: 10.1016/j.jclepro.2020.124009.

[4] A Magyar Energetikai és Közmű-szabályozási Hivatal Kiadványa, Magyarország geotermikus felmérése. 2016.

[5] M. Kaczmarczyk, B. Tomaszewska, and L. Pajak, "Geological and thermodynamic analysis of low enthalpy geothermal resources to electricity generation using ORC and Kalina cycle technology," Energies, vol. 16, no. 3, 2020, doi: 10.3390/en13061335.

[6] B. Líndal, "Review of industrial applications of geothermal energy and future considerations," Geothermics, vol. 21, no. 5-6, pp. 591-604, 1992, doi: 10.1016/03756505(92)90012-X. 
[7] J. Twidell and T. Weir, Renewable energy sources, Oxon. Routledge, 2015.

[8] B. Tomaszewska and A. Operacz, "Sustainable Utilization of Low Enthalpy Geothermal," 2020.

[9] G. L.Szabó, "Geotermális energiával müködtetett abszorpciós hűtőgép és hőellátó távvezetékének energetikai elemzése a hõforrás hõmérsékletének szempontjából," Magy. Épületgépészet, vol. 9, 2011.

[10] G. L.Szabó, “Thermo-Chemical Instability and Energy Analysis of Absorption Heat Pumps," energies, vol. 13, no. 1966, 2020, doi: doi:10.3390/en13081966.

[11] Z. Verbai, Á. Lakatos, and F. Kalmár, "Prediction of energy demand for heating of residential buildings using variable degree day," Energy, vol. 76, pp. 780-787, Nov. 2014, doi: 10.1016/j.energy.2014.08.075.

[12] F. Szodrai, Á. Lakatos, and F. Kalmár, "Analysis of the change of the specific heat loss coefficient of buildings resulted by the variation of the geometry and the moisture load," Energy, vol. 115, pp. 820-829, 2016, doi: 10.1016/j.energy.2016.09.073.

[13] 7/2006 TNM, Decree on the Determination of the Energy Characteristics of Buildings. 2006.

[14] T. Huld, R. Müller, and A. Gambardella, "A new solar radiation database for estimating PV performance in Europe and Africa," Sol. Energy, vol. 86, no. 6, pp. 1803-1815, 2012, doi: 10.1016/j.solener.2012.03.006.

[15] I. Csáky, "Analysis of Daily Energy Demand for Cooling in Buildings with Different Comfort Categories-Case Study," energies, vol. 14, no. 4694, 2021, doi: 10.3390/en14154694.

[16] Eurostat, "Natural gas price statistics," 2021. https://ec.europa.eu/eurostat/statisticsexplained/index.php/Natural_gas_price_statistics.

[17] Eurostat, "Electricity price statistics," 2021. https://ec.europa.eu/eurostat/statisticsexplained/index.php/Electricity_price_statistics\%0A. 